\title{
Organisational and Task Factors Influencing Teachers' Professional Development at Work
}

Citation for published version (APA):

Evers, A., Van der Heijden, B., \& Kreijns, K. (2016). Organisational and Task Factors Influencing Teachers' Professional Development at Work. European Journal of Training and Development, 40(1), 36-55.

https://doi.org/10.1108/EJTD-03-2015-0023

\section{DOI:}

10.1108/EJTD-03-2015-0023

Document status and date:

Published: 01/01/2016

Document Version:

Peer reviewed version

\section{Document license:}

CC BY-NC-ND

Please check the document version of this publication:

- A submitted manuscript is the version of the article upon submission and before peer-review. There can be important differences between the submitted version and the official published version of record. People interested in the research are advised to contact the author for the final version of the publication, or visit the DOI to the publisher's website.

- The final author version and the galley proof are versions of the publication after peer review.

- The final published version features the final layout of the paper including the volume, issue and page numbers.

Link to publication

\section{General rights}

Copyright and moral rights for the publications made accessible in the public portal are retained by the authors and/or other copyright owners and it is a condition of accessing publications that users recognise and abide by the legal requirements associated with these rights.

- Users may download and print one copy of any publication from the public portal for the purpose of private study or research.

- You may not further distribute the material or use it for any profit-making activity or commercial gain

- You may freely distribute the URL identifying the publication in the public portal.

If the publication is distributed under the terms of Article 25fa of the Dutch Copyright Act, indicated by the "Taverne" license above, please follow below link for the End User Agreement:

https://www.ou.nl/taverne-agreement

Take down policy

If you believe that this document breaches copyright please contact us at:

pure-support@ou.nl

providing details and we will investigate your claim.

Downloaded from https://research.ou.nl/ on date: 26 Apr. 2023 
Running head: Factors Influencing Teachers' Professional Development at Work

\title{
Full title: Organisational and Task Factors Influencing Teachers' Professional Development at Work ${ }^{1}$
}

\author{
Arnoud T. Evers (corresponding author) \\ Open University of the Netherlands \\ Welten Institute, Research Centre for Learning, Teaching and Technology \\ Valkenburgerweg 177 \\ 6401 DL Heerlen \\ Telephone number: +31-(0)45-5762925 \\ Fax number: +31-(0)45-5762782 \\ E-mail address: arnoud.evers@ou.nl \\ Béatrice I. J. M. Van der Heijden \\ Radboud University, Institute for Management Research, the Netherlands \\ PO box 9108 \\ 6500 HK Nijmegen \\ Telephone number: +31-(0)24-3615454 \\ E-mail address: B.vanderHeijden@fm.ru.nl \\ Open University of the Netherlands \\ School of Management \\ Karel Kreijns \\ Open University of the Netherlands \\ Welten Institute, Research Centre for Learning, Teaching and Technology \\ Valkenburgerweg 177 \\ 6401 DL Heerlen, the Netherlands \\ Telephone number: +31-(0)45-5762574 \\ E-mail address: karel.kreijns@ou.nl
}

\footnotetext{
${ }^{1}$ See for the article as published online: http://dx.doi.org/10.1108/EJTD-03-2015-0023. Please refer to this article as: Evers, A. T., Van der Heijden, B. I. J. M., Kreijns, K. (2016). Organisational and task factors influencing teachers' professional development at work. European Journal of Training and Development, 40(1), 36-55.
} 


\section{Structured Abstract}

\section{Purpose}

The development of life-long learning competencies and, consequently, the careers of teachers, has become a permanent issue on the agenda of schools worldwide. The workplace is also increasingly regarded as the place to develop these competencies. The main purpose of this article is to investigate organisational (cultural and relational) and task factors which potentially enhance Teachers' Professional Development (TPD) at Work.

Methodology

A model incorporating the relationships between organisational and task factors as predictor variables, and TPD at Work as the dependent, is presented and tested empirically by a quantitative (survey research) method.

\section{Findings}

The study results indicated that learning climate, social support from one's immediate supervisor, social support from close colleagues, and learning value of the function can act as important job resources for TPD at Work. Work pressure and emotional demands, on the other hand, appeared to act as job demands for TPD at Work, but also have the potential to enhance TPD at Work.

Research limitations

The most important limitations of the study were the cross-sectional nature and the use of self-ratings only, which may imply common-method bias.

Practical implications

To enhance TPD at Work, it is vital for actors inside and outside schools to focus on the right working conditions (as mentioned under findings) in schools, so that teachers can learn from their job.

Originality

Knowledge in schools and empirical research about which factors at the organisational and task level are important to enhance TPD at Work seems scarce. This research contributes to this knowledge gap. 


\section{Introduction}

Schools across the Netherlands, and in many countries worldwide, are challenged to guarantee high-quality teaching to their pupils (Commissie Leraren, 2007; National Staff Development Council, 2009; OECD, 2009, 2013). This challenge is three-folded. First, schools are faced with an increasing shortage of teachers, both in terms of quality and quantity, due to the ageing of the teachers' population, on the one hand, and the decrease in new teachers entering the labour market, on the other hand (Commissie Leraren, 2007). This quantitative shortage may tempt schools to attract unqualified teachers, or to give them more responsibilities than they are authorized to. Therefore, schools risk that the quality of their teaching is declining with, presumably, severe negative consequences for their learners' performance (Cornet et al., 2006).

In addition, this risk of a decline in the quality of teaching may be exacerbated by the second challenge schools are facing, namely, the transformation of our post-industrial society into a knowledge- and technology-based one. This means that learners and teachers have to possess so-called ' $21^{\text {st }}$-century skills' that are needed to cope with the requirements of tomorrow's society (Somekh, 2005). Therefore, Teachers' Professional Development (TPD) and teachers' careers, have become an important issue on the agenda of schools worldwide (Rippon, 2005). Traditionally, professional development of workers is organized by Human Resource Management (HRM) departments in large organisations. Hill and Stewart (2000) already suggested that small and medium-sized enterprises do not have the HRM expertise, general resources and infrastructure which large organisations more frequently enjoy. Also, in school organizations, if existing, nowadays, such departments are very small.

This brings us to the third challenge schools are facing currently: not having the knowledge about which factors are important to enhance TPD, and, more specifically, TPD at Work. HRM professionals should obtain more insights into the matter of how to develop 
employees, that is teachers, in a (school) organisation (McGoldrick et al., 2002; McGuire and Cseh, 2006). An often heard criticism is that researchers focus on just a few variables, herewith implying an isolated picture of reality. In order to respond to this shortcoming, the goal in this study was to look at TPD at Work in an integrative way. This is why we focused on the broader categories of organisational and task factors influencing TPD at Work, which implied including a relatively large number of independent variables. Therefore, the central research question is: "Which organisational and task factors are key to enhance TPD at Work?" In answering this question, the influence of a larger set of assumed predictors for TPD at Work will be empirically tested.

\section{Theoretical Outline}

\section{TPD at Work: Participation in Professional Learning Activities}

In addition to formal learning, the range of possible learning activities at the workplace has been broadened to include informal learning at work as well (Cheetham and Chivers, 2001; Eraut, 2004; Tynjälä, 2008). Marsick and Watkins (2001, p. 25) defined informal learning in education as “[.....] not typically classroom-based or highly structured, and control of learning rests primarily in the hands of the learner." Based on Avalos (2011), Brookfield (1995), Evers (2012), Geijsel et al. (2009), and Kwakman (2003), in this contribution, the focus is on TPD at Work. TPD at Work is defined as participation in the following formal and informal learning activities: 1) Keeping up-to-date: reading; 2) Keeping up-to-date: participation in training related to work; 3) Experimenting; 4) Reflecting and asking for feedback, 5) Collaborating with colleagues with the aim of improving the lessons; and 6) Collaborating with colleagues with the aim of improving school development.

First, according to Kwakman (2003), a critical goal of reading is keeping up-to-date by gaining new insights and advancements in one's professional field. The importance of getting 
acquainted with domain-specific knowledge was also stressed by Brookfield (1995). Second, in addition to Kwakman (2003), and in accordance with Geijsel et al. (2009), 'participation in training related to work', being a TPD at Work activity, is also included in our research model. In order to increase its practical value, it is essential that the content of training has a strong connection to daily work activities of teachers (see also Postholm, 2012). Third, experimenting comprises an intentional effort of teachers to undertake something new within the classroom (Kwakman, 2003). Fourth, reflecting and asking for feedback (Avalos, 2011; Runhaar, 2008), implies stepping back from an experience, in order to consider the meaning of that experience to the self through the analysis of its consequences (Retallick, 1999). This learning activity coincides with Brookfield's (1995) emphasis on self-reflection and student feedback. Finally, collaboration is essential for one's professional development as it provides employees, in this case teachers, the necessary support for learning, offers them a basis for critical thinking, and entails new challenges and ideas (Evers, 2012; Kwakman, 2003). Moreover, Little (1990) already concluded that the content of collegial interaction is very important in the light of the contribution or added value of collaboration with colleagues to TPD. In a similar vein, Brookfield (1995) stressed the importance of engaging with peers. Therefore, we will focus specifically on two types of collaboration with colleagues that centre on its content: collaborating with colleagues with the aim of improving the lessons, being the fifth learning activity, and collaborating with colleagues with the aim of improving school development, being the sixth one.

\section{Organisational Factors}

Following the subdivision as mentioned in Evers et al. (2011), two levels of organisational factors were incorporated in this study: 1) cultural factors, and 2) factors referring to socialpsychological relations. These types of factors can be perceived as being job resources and are hypothesized to influence participation in professional learning activities (see also Bakker and 
Demerouti, 2007; Evers et al., 2011). Job resources are characterized as those factors that foster employees' growth, learning and development (Bakker and Demerouti, 2007; Bakker et al., 2010), and form part of the Job Demands-Resources (JD-R) model. The JD-R model will be explained further on in the section on Task factors. We will now first discuss the so-called cultural factors.

\section{Cultural Factors}

Culture is described as a deeper, less consciously, held set of cognitions and affective attachments (Mikkelsen and Grønhaug, 1999). Drawing from prior literature (Stol et al., 2006; Van Woerkom, 2003) two cultural factors which are believed to be essential for the professional development of teachers at work were identified: 1) learning climate and 2) team membership.

Learning climate. Learning climate is characterized as the time spent on collective reflection, the amount of contacts between different teams and departments in an organisation, learning from the practices of other organisations, and the tolerance towards the different opinions of 'mavericks' (Van Woerkom, 2003). Learning climate is an important condition to be fulfilled for the actual learning behaviour at work to take place. Marsick and Watkins (2001) noted that these kinds of stimuli (the characteristics of the learning climate) in an organisation indeed may trigger informal learning in the workplace. In addition, given the outcomes of previous research (Van Woerkom et al., 2002), it is assumed that learning climate is an important positive predictor of TPD at Work.

Team membership. O’Leary et al. (2011) described how team membership potentially contributes to learning. Nowadays, team work in schools is more and more stimulated (Commissie Leraren, 2007). An important goal of team work is to grow towards a 'collegial organisation' wherein teachers are jointly accountable for the school's culture and performance. As in such an organisation more frequent meetings take place and as 
collaboration in networks is stimulated (Stol et al., 2006), it is assumed that a teachers' team membership positively influences TPD at Work.

Now that we have discussed cultural factors, we will continue with factors referring to social-psychological relations and their assumed impact upon TPD at Work.

\section{Social-Psychological Relations}

A social-psychological relationship is built up through the natural and repeated action and communications among the partners (Sahlstein and Duck, 2001). Based on previous literature (Evers et al., 2011), the following factors comprising social-psychological relations were taken into account in this empirical study: 1) transformational leadership, 2) career possibilities offered by the supervisor, 3) social support from one's immediate supervisor, and 4) social support from one's close colleagues.

Transformational leadership is a leadership style that refers to leaders having the ability to give a clear vision for the future, to inspire employees, to stimulate employees to develop their talents in the best possible way, and to give their work a deeper meaning (De Hoogh et al., 2004). Previous research has indicated that 'transformational leadership' contributes to the professionalization of teachers (Geijsel et al., 2009; Runhaar, 2008). Recently, Fullan (2014) even stressed that one of the school leaders' main roles is to lead learning. Therefore, a positive influence of this leadership style on TPD at Work activities was expected as well.

Career possibilities offered by the supervisor. Career possibilities comprise the career growth opportunities (e.g., opportunities for promotion) offered by the organisation for their employees (Van Veldhoven and Meijman, 1994). A lack of these kinds of possibilities may severely hamper employees' (cognitive) development (Van der Heijden, 2003). Indeed, according to Skule (2004), career opportunities shape the conditions for learning at work. In 
schools, the supervisor is the main actor who can offer the career possibilities to teachers. It is, therefore, hypothesized that this factor positively influences TPD at Work.

Social support from one's immediate supervisor and close colleagues. In accordance with House (1981) and Van der Heijden (2003), four functions of social support for teachers were distinguished. The first function is instrumental, with the support being oriented towards the accomplishment of tasks. The second function is emotional, with the support being oriented towards the emotional aspects of accomplishing the task. The third function comprises informational support: it assists individuals to help themselves so that they are enabled to proceed with their tasks. The fourth function is appraisal support, which entails the transmission of information that is relevant to self-evaluation. The value of support of one's immediate supervisor for learning on the job was already demonstrated in previous empirical studies of Felstead et al. (2005) and Blokhuis (2006). As regards social support from close colleagues, Kwakman (2003) found a positive relationship between collegial support and certain learning activities for teachers in secondary education. In addition, Berings et al. (2010) found direct and indirect effects of social support by the supervisor and indirect effects of social support by colleagues on learning behaviours. In line with this all, social support from one's immediate supervisor and from close colleagues was expected to be (positively) related to TPD at Work activities.

Based on the theoretical outline given above, the following hypothesis was formulated:

Hypothesis 1. Organisational factors, more specifically, cultural (learning climate and team membership), and social-psychological relations (transformational leadership, career possibilities offered by the supervisor, social support from one's immediate supervisor, and social support from close colleagues) are positively related to TPD at Work activities. 
In the next section, we will discuss task factors that are also hypothesized to have a positive influence on TPD at Work activities.

\section{Task Factors}

An important and relevant theory that incorporates task factors is the JD-R model (Demerouti et al., 2001). Job (or task) demands are defined as "stress sources (stressors), such as work load demands, present in the work environment" (Karasek, 1979, p. 287). Job resources refer to resources at the level of the organisation at large (see above) and at the level of the task (Bakker and Demerouti, 2007). In this study, the focus lies on the direct effects of demands and resources upon TPD at Work activities (see also Bakker and Demerouti, 2007). First, two task demands' factors will be discussed: (1) work pressure and (2) emotional demands. Next, three task resources' factors will be elaborated on: (1) autonomy, (2) the learning value of the function and (3) tasks apart from teaching.

Work pressure and emotional demands. Work pressure is defined as "quantitative demanding aspects such as the pace of work and workload" (Kwakman, 2003, p. 161). Kwakman (2003) found a direct positive significant effect of work pressure on participation of teachers in two types of TPD: collaborative activities and instructional activities. Van Ruysseveldt and Van Dijke (2011) found a positive relationship between workload and learning activities but only at low and moderate levels of workload and moderate levels of autonomy. Emotional demands refer to "the extent to which the teaching job requires emotional investment" (Kwakman, 2003, p. 161). Again, Kwakman (2003) found a direct positive effect of emotional demands on three types of TPD at Work activities: collaborative activities, individual activities and instructional activities. Moreover, positive, significant, albeit small, effects of work pressure and emotional demands on participation in professional learning activities have also been reported by Kwakman (2001). Therefore, work pressure and 
emotional demands have been hypothesized to influence participation in TPD at Work activities in a positive way.

Hypothesis 2. Task demands' factors, more specifically, work pressure and emotional demands, are positively related to TPD at Work activities.

Autonomy. Autonomy, being an essential factor related to learning and growing of teachers (Bakker and Demerouti, 2007; Hoekstra, 2007; Kwakman, 2003), refers to "the opportunity of the teacher to determine different task-related characteristics" (Kwakman, 2003, p. 161). Van Ruysseveldt and Van Dijke (2011) found that low levels of autonomy was jeopardizing the positive effects of a low to moderate workload to learning activities whereas high levels of autonomy makes a high workload less destructive for learning activities. In addition, autonomy has proven to improve feedback practices (Lee, 2008). Lui and Fu (2011) studied autonomy support from three different sources on personal learning in teams. They found all three autonomy sources to be predictors for personal learning. Therefore, autonomy, in general terms, was expected to positively influence TPD at Work activities.

Learning value of the function. The following task factor that is incorporated in our model comprises the learning value of the function for the employee him or herself (Van der Heijden, 1998; Van der Heijden et al., 2005). This was defined as "the value which the function has as a nutrient for the employee's further professional development" (Boerlijst et al., 1993, p. 57). Therefore, the learning value of the function was expected to be a positive predictor for TPD at Work activities.

Tasks apart from teaching. Tasks that teachers have to fulfil apart from teaching may be beneficial for their learning as well. After all, additional tasks may stimulate them to think about their teaching expertise, and to further develop these. Kwakman (2003) already found that job variety, a related concept, had a positive effect on collaborative (learning) activities. 
Stok-Koch et al. (2007) found, amongst others, that task variation was a factor influencing workplace learning. From the theoretical outline given above, it was hypothesized that:

Hypothesis 3. Task resources' factors, more specifically, autonomy, learning value of the function, and tasks apart from teaching are positively related to TPD at Work activities.

For sake of clarity, the discussed relationships are visualized in the following model (see Figure 1):

\section{Method}

$* * * * * *$ Insert Figure 1 about here******

In order to investigate the relationships as depicted in Figure 1, and to test its accompanying hypotheses, we adopted a quantitative survey approach. More concrete, we have used a webbased survey, except for one school, as this has the advantage of efficient data collection, and as it limits the number of missing items. We have tested our hypotheses by means of multiple hierarchical regression analyses.

\section{Sample and Procedure}

Data was collected by means of a survey study that was administered in nine Dutch primary schools and in 15 Dutch secondary schools (these teachers were located in 34 secondary school locations). The survey was pilot tested among several experts in the field of primary and secondary education (teachers and directors) in order to examine the face validity of its operationalization. The survey was web-based, except for one school, where a paper-andpencil form was used. In total, 2,385 teachers were approached (two reminders to each school were sent individually) of whom in total 692 (118 primary teachers and 574 secondary teachers) returned a completely filled out survey. This implied a total response rate of $29 \%$. 
For on-line questionnaires, this response rate is quite common (Sheehan, 2001). The final sample characteristics are shown in Table 1.

$* * * * * *$ Insert Table 1 about here $* * * * * *$

\section{Measures}

TPD at Work. The scales for TPD at Work were based on the previously validated instrument by Evers et al. (accepted), utilizing a 4 -point rating scale $(1=$ hardly ever to $4=$ often). Teachers were asked to indicate how often they participated in each professional learning activity. The first scale, keeping up to date: reading, consisted of three items. Cronbach's alpha was .73. An example item was: "Studying subject matter literature." The second scale, keeping up-to-date: participation in training related to work, had two items. Cronbach's alpha comprised .72. An example item was: "Participation in a training course that centres around subject matter pedagogy." The third scale, experimenting, consisted of five items. An example item was: "Testing alternative teaching materials in class." Cronbach's alpha was .80. Reflecting and asking for feedback, the fourth scale, had four items. An example item was: "Adapting my teaching methods in response to pupils' reactions." Cronbach's alpha was .67. Three items were used for the fifth scale, collaborating with colleagues with the aim of improving lessons. Cronbach's alpha comprised .67. An example item was: "Preparing lessons with colleagues." Finally, the sixth scale, collaborating with colleagues with the aim of improving school development, was based on four items. An example item was: "Give an opinion together with colleagues about school organisational matters to the school management." Cronbach's alpha was .73.

Cultural factors: Team membership. This was measured by means of one question: "Are you currently a member of a team?"

Cultural factors: Learning climate. To create the scale for learning climate, the learning climate scale of Van Woerkom (2003) was shortened and slightly adjusted, in order to make it 
suitable for an educational setting. This resulted in a final scale consisting of five items. All items were measured on a 4 -point scale (ranging from $1=$ hardly ever to $4=$ always). An example item was: "Time is reserved to work together on our professional development." Cronbach's alpha was .70.

Social-psychological relations: Transformational leadership. This scale was assessed by the scale of De Hoogh et al. (2004). The eleven items were measured on a 7-point rating scale (ranging from $1=$ totally disagree to $7=$ totally agree). An example item was: 1 ) "My immediate supervisor encourages employees to think independently." Cronbach's alpha comprised .95 .

Career possibilities offered by the supervisor. This scale was based on a scale by Van Veldhoven and Meijman (1994). The two most relevant items for teachers were selected and 'my job' was replaced by 'my immediate supervisor' and 'employees' was added to the items. It consisted of two items 1): "My immediate supervisor offers employees financial grow opportunities." and 2): "My immediate supervisor offers employees opportunities for promotion." The same rating scale as for transformational leadership was used (ranging from $1=$ totally disagree to $7=$ totally agree). Cronbach's alpha was .90 .

Social-psychological relations: Social support from one's immediate supervisor and social support from close colleagues. These scales were both measured with four items using the thoroughly validated 6-point rating scales by Van der Heijden (2002, 2003). An example item was: "Is your immediate supervisor in general ready to help you with the performance of your tasks?" (ranging from: (1) "in my opinion, (s) he shows little willingness to help me" to (6) "in my opinion, (s) he is very willing to help me"), and "are close colleagues in general ready to help you with the performance of your tasks?" Cronbach's alpha's were respectively .85 and .78 . 
Task factors: Work pressure. The measurement scale for work pressure consisted of seven items (Kwakman, 2003; originally Van Veldhoven and Meijman, 1994), and utilized a 4-point scale (ranging from $1=$ hardly ever to $4=$ always). An example item was: "Are you working under time pressure?" Cronbach’s alpha was .74.

Task factors: Emotional demands. The scale emotional demands used four items (Kwakman, 2003; originally Van Veldhoven and Meijman, 1994), and also utilized a 4-point scale (ranging from 1 = hardly ever, to 4 = always). An example item was: "Are you confronted in your work with aspects that affect you personally?" Cronbach's alpha comprised .67.

Task factors: Autonomy, referring to teachers' possibility to decide on different taskrelated characteristics, like the pace of work, the method, and work order was measured by means of five items from the VBBA (Van Veldhoven and Meijman, 1994). These items were regarded as most suitable for the teaching profession (Kwakman, 2003). Again a 4-point scale (ranging from $1=$ hardly ever to $4=$ always) was used. An example item was: "Do you have influence on the pace of work?" Cronbach's alpha comprised .82 .

Task factors: Learning value of the function. To measure learning value of the function the validated scale by Van der Heijden (1998) (see also Van der Heijden et al., 2005; Van der Heijden and Bakker, 2011) was used. This scale comprises six items, each using a 6-point scale (ranging from $1=$ strongly disagree to $6=$ strongly agree). An example of an item was: “My job enables me to further develop my talents." Cronbach's alpha was .86.

Task factors: Tasks apart from teaching. This variable was measured by means of one item: "Do you currently fulfil other tasks than teaching?"

The following demographic characteristics were incorporated as control variables in our study: primary/secondary education, gender, educational qualification and age. Primary education serves as the reference category for education. For gender, women serves as the 
reference category. Gender, educational qualification and age are often used as control variables in research about professional development and previously some significant effects have indeed been found (e.g., Runhaar, 2008).

\section{Results}

\section{Descriptive Statistics}

In Table 2, the descriptive statistics (means, standard deviations, reliability coefficients, and inter-correlations between all model variables) are shown. As Table 2 shows, most indices appeared to have sufficient alpha levels of $>.70$ (Nunnally, 1978). However, three indices appeared to have a Cronbach's alpha between .60 and .70. Scale reliabilities for emotional demands, reflecting and asking for feedback, and collaborating with colleagues with the aim of improving the lessons were in all cases .67. According to Loewenthal (2001), a slightly lower index (of about .60), is acceptable in case: 1) there is good evidence for validity, 2) there are good theoretical reasons for the scale operationalization and when 3) the scale is relatively short (less than about 10 items). These criteria applied to all of the three indices.

$$
\text { ******Insert Table } 2 \text { about here****** }
$$

\section{Outcomes of the Regression Analyses}

\section{The Influence of Organisational and Task Factors on TPD at Work Activities}

In order to test the relationship between the organisational and task factors, on the one hand, and participation in TPD at Work activities, on the other hand, multiple hierarchical regression analyses have been performed (see Table 3 for the specific outcomes). In the first step of the regression analysis, the demographic characteristics primary/secondary education, gender, educational qualification and age were entered as control variables. In step two, the cultural influencing factors were entered. In step three, the social-psychological relations were entered. Finally, the task factors were entered in step four of the regression analysis. This is 
the order as explained in Evers et al. (2011) and which follows logically from the theoretical framework and hypotheses, see also Figure 1.

Hypothesis 1 stated that the organisational factors learning climate, team membership, transformational leadership, social support from one's immediate supervisor, career possibilities offered by the supervisor, and social support from close colleagues are positively related to TPD at Work activities. This hypothesis was partly supported in the study. As can be seen from Table 3, from the cultural factors, learning climate appeared to be the most important predictor, influencing participation in training related to work $(\beta=.10, p<.05)$ and collaborating with colleagues with the aim of improving school development $(\beta=.09, p<$ .05). Team membership appeared to be not related to TPD at Work activities.

As Table 3 shows, as regards social-psychological relations, social support from one's immediate supervisor and social support from close colleagues appeared to have the highest impact on the participation in TPD at Work activities. Social support from one's immediate supervisor appeared to have a positive influence on reflecting and asking for feedback $(\beta=$ $.15, p<.01)$, and on collaborating with colleagues with the aim of improving school development $(\beta=.16, p<.01)$. Social support from close colleagues appeared to have a positive influence on experimenting $(\beta=.10, p<.05)$, on reflecting and asking for feedback $(\beta=.15, p<.01)$, on collaborating with colleagues with the aim of improving the lessons $(\beta=$ $.32, p<.01)$, and on collaborating with colleagues with the aim of improving school development $(\beta=.18, p<.01)$. Surprisingly, transformational leadership and career possibilities offered by the supervisor did not have a significant impact on any of the TPD at Work activities.

$$
\text { *******Insert Table } 3 \text { about here****** }
$$

Hypothesis 2 stated that work pressure and emotional demands are positively related to TPD at Work activities. This hypothesis was partly confirmed with the data as well. Work pressure 
positively influenced reflecting and asking for feedback $(\beta=.13, p<.01)$, collaborating with colleagues with the aim of improving the lessons $(\beta=.11, p<.01)$, and collaborating with colleagues with the aim of improving school development $(\beta=.15, p<.01)$. Emotional demands appeared to significantly influence keeping up-to-date: reading $(\beta=.09, p<.05)$ and reflecting and asking for feedback $(\beta=.10, p<.01)$.

Hypothesis 3 stated that autonomy, learning value of the function, and tasks apart from teaching are positively related to TPD at Work activities. Again this hypothesis was only partly supported. The learning value of the function was the most influential factor, it positively influenced reading $(\beta=.16, p<.01)$ and reflecting and asking for feedback $(\beta=$ $.17, p<.01)$. Tasks apart from teaching, surprisingly, appeared to have a (although small) negative influence on the participation in collaborating with colleagues with the aim of improving the lessons $(\beta=-.07, p=.05)$. However, as expected, it did have a positive influence on collaborating with colleagues with the aim of improving school development $(\beta$ $=.18, p<.01)$. Finally, autonomy appeared not to be related to any of the TPD at Work activities.

In conclusion, in particular the organisational factors learning climate, social support from one's immediate supervisor, social support from close colleagues, and the task factor learning value of the function can act as positive job resources for TPD at Work activities.

\section{Conclusions and Discussion}

\section{Reflections}

The findings of our quantitative study provided support that learning climate, social support from one's immediate supervisor, social support from close colleagues, and learning value of the function are main job resources with respect to teachers' participation in TPD at Work activities. These predictors explained a significant amount of variance on teachers' 
participation in TPD at Work activities and are comparable to the resources' factors that Xanthopoulou et al. (2007) used in their JD-R model research. Only autonomy appeared, contrary to our expectations, not to have a direct effect on TPD at work activities.

From our findings it is essential for school management and HRM professionals not to neglect these influencing factors when setting up a professional development trajectory in schools. First of all, school management should be aware that job demands (such as work pressure and emotional demands) are not necessarily negatively related to possibilities for learning. Rather they might even enhance learning but their levels should be monitored in order to prevent health-related problems and even exhaustion (see Bakker and Demerouti, 2007). Furthermore, the learning value of the function and learning climate should enable the employee's further professional development (Boerlijst et al., 1993). Another finding from our study is that tasks which teachers have to fulfil apart from teaching is negatively influencing collaboration to improve the lessons, and positively influencing collaboration to improve school development. This could indicate that these types of additional tasks are especially focused on activities to improve school development. Possibly, a further attention for exchanging lesson content knowledge-for instance by task circulation among pairs of teachers - might result in positive effects with regard to collaboration to improve the lessons as well.

Finally, our findings showed that, surprisingly, transformational leadership, team membership, career possibilities offered by the supervisor, and autonomy had no direct influence on TPD at Work activities. Although it is useful to investigate direct effects of our hypothesized influencing factors, it could be that other (personal) variables play a mediating role between these conditions and actual TPD at Work learning behaviour. 


\section{Limitations and Recommendations for Further Research}

Our study has a number of limitations. First, the study is cross-sectional (i.e., all data have been collected at one point in time). In order to address issues of causality, it would be valuable to examine the proposed model in a longitudinal study. Second, the study was specifically aimed at the teaching profession, so further research is necessary to investigate its generalizability to other occupations and/or countries as well. Third, because self-ratings have been used for the predictors and the outcome variables, there is a risk for common-method bias. More specific, Van der Heijden (1998) found that employees rate themselves significantly higher on occupational expertise, compared to their supervisors. This could imply a 'leniency effect' (Cascio, 1991). The common-method bias might be combated by using other rating sources as well, for instance, one's direct supervisor or close colleagues, or pupils' ratings.

Fourth, Hox (2002) stated that statistical interdependence can be neglected if the variance attributed to the grouping variable is around $5 \%$ or less (Hox, 2002). The variances attributed to the grouping variable (the Intra-Class Correlation) for collaborating with colleagues with the aim of improving the lessons, and collaborating with colleagues with the aim of improving school development, were both above this level, $13.14 \%$ and $11.00 \%$, respectively. Therefore, for these dependent variables, correlation and regression effects could be somewhat overestimated. Future research ought to include multi-level analyses for these learning activities. Fifth, an interesting next phase in exploring the relationship between the resources that have been found to be significant predictors (learning climate, social support from one's immediate supervisor, social support from close colleagues, and learning value of the function) and TPD at Work, could be to investigate how these resources work together in enhancing this type of learning. Finally, further research is necessary to better understand why transformational leadership, team membership, career possibilities offered by the supervisor, 
and autonomy had no effect on TPD at Work activities. Possibly, other (personal) variables, like self-efficacy beliefs (Bandura, 1989; Fishbein and Ajzen, 2010), or flow (see also Van der Heijden and Bakker, 2011) play a mediating role between these factors and actual participation in TPD at Work learning behaviour.

\section{Practical Implications}

The results in this article suggest that management and HRM professionals in schools should stimulate social support given to employees and among colleagues, in order to create a work environment where TPD at Work flourishes. Maybe employees' first thought when thinking about possible ways of receiving social support is colleagues being willing to listen to their problems or giving them a compliment (and in this way to give emotional support), which indeed is very important, also for learning on the job. However, it is equally necessary to give instrumental (focusing on accomplishing tasks), informational (helping colleagues to proceed with their tasks) or appraisal (input for one's self-evaluation) support. Furthermore, to stimulate TPD at Work, it is vital for school management and HRM professionals to make sure that teachers can learn from their job. This means safe-guarding that the function of teachers itself keeps having enough potential for learning and development. This might be done, for example, by enabling them to perform diverse tasks and integrating cooperation between teachers before, during and after teaching. It is also critical to strive for a sound learning climate, where different opinions are valued.

Work organisations, with schools being no exception, change rapidly, and individual employees are more and more urged to develop themselves continuously in order to adapt and to stay in a desired job. Notwithstanding the increasing individual's responsibility for lifelong employability (Van der Heijden et al., 2009), the working organisation is still a key factor in professional and career development. The research that is reported in this article 
indicates that school organizations have ample opportunities to stimulate TPD at work, herewith, enhancing teachers' career potential or employability (see also Van der Heijden et al., 2015). Perceptions of teachers indicating that their school's management provides sound leadership, support and concern about their further development, is of utmost importance in this regard. Moreover, teachers' jobs have to represent challenging constellations of tasks and responsibilities (see also Van der Heijden and Bakker, 2011), wherein they have ample opportunities for learning throughout their entire career. And last but not least, teachers should work in an environment wherein they experience a supportive learning climate with high-quality relationships and wherein both their immediate supervisor and close colleagues are willing to help them and wherein it is safe to make mistakes. 


\section{References}

Avalos, B. (2011), "Teacher professional development in Teaching and Teacher Education over ten years", Teaching and Teacher Education, Vol. 27 No. 1, pp. 10-20.

Bakker, A.B. and Demerouti, E. (2007), "The job demands-resources model: State of the art", Journal of managerial psychology, Vol. 22 No. 3, pp. 309-328.

Bakker, A.B., Van Veldhoven, M. and Xanthopoulou, D. (2010), "Beyond the DemandControl model: Thriving on High Job Demands and Resources", Journal of Personnel Psychology, Vol. 9 No. 1, pp. 3-16.

Bandura, A. (1989), "Human agency in social cognitive theory", American Psychologist, Vol. 44 No. 9, pp. 1175-1184.

Berings, M., Van Veldhoven, M. and Poell, R.F. (2010), “Antecedents of nursus' actual learning activities: The role of psychological work conditions and intrinsic work motivation", in Van Woerkom, M. and Poell, R.F. (Eds), Workplace learning: Concepts, measurement and application, Routledge, London, pp. 71-87.

Blokhuis, F.T.L. (2006), Evidence-based design of workplace learning, Doctoral dissertation, University of Twente, Enschede, the Netherlands.

Boerlijst, J.G., Van der Heijden, B.I.J.M. and Van Assen, A. (1993), Veertig-plussers in de onderneming [Over-forties in the organisation], Van Gorcum/Stichting Management Studies, Assen.

Brookfield, S. (1995), Becoming a Critically Reflective Teacher, Jossey-Bass, San Francisco.

Cascio, W.F. (1991), Applied psychology in personnel management, Prentice-Hall International, London.

Cheetham, G. and Chivers, G. (2001), "How professionals learn in practice: an investigation of informal learning amongst people working in professions", Journal of European Industrial Training, Vol. 25 No. 5, pp. 248-292.

Commissie Leraren. (2007), Leerkracht! [Teacher!], DeltaHage, Den Haag. 
Cornet, M., Huizinga F., Minne, B. and Webbink, D. (2006), Kansrijk kennisbeleid (Report No. 124), Centraal Planbureau, Den Haag.

De Hoogh, A.H.B., Den Hartog, D.N. and Koopman, P.L. (2004), "De ontwikkeling van de CLIO: een vragenlijst voor charismatisch leiderschap in organisaties [The development of the CLIO: a questionnaire for charismatic leadership in organizations]", Gedrag \& Organisatie, Vol. 17 No.5, pp. 354-382.

Demerouti, E., Bakker, A.B., Nachreiner, F. and Schaufeli, W.B. (2001), “The job demandsresources model of burnout", Journal of Applied Psychology, Vol. 86 No. 3, pp. 499512.

Eraut, M. (2004), “Informal learning in the workplace”, Studies in continuing education, Vol. 26 No. 2, pp. 247-273.

Evers, A.T. (2012), Teachers' Professional Development at Work and Occupational Outcomes: An Organisational and Task Perspective, Unpublished doctoral dissertation, Open Universiteit, Heerlen.

Evers, A.T., Kreijns, K. and Van der Heijden, B.I.J.M. (2016), “The design and validation of an instrument to measure teachers' professional development at work", Studies in Continuing Education, Vol. 38 No. 2, pp. 162-178.

Evers, A.T., Kreijns, K., Van der Heijden, B.I.J.M. and Gerrichhauzen, J.T.G. (2011), “An Organizational and Task Perspective Model Aimed at Enhancing Teachers' Professional Development and Occupational Expertise", Human Resource Development Review, Vol. 35 No. 1 , pp. 24-44.

Felstead, A., Fuller, A., Unwin, L., Ashton, D., Butler, P. and Lee., T. (2005), “Surveying the scene: learning metaphors, survey design and the workplace context", Journal of education and Work, Vol. 18 No. 4, pp. 359-383. 
Fishbein, M. and Ajzen, I. (2010), Predicting and changing behaviour: The reasoned action approach, Psychology Press, New York, NY.

Fullan, M. (2014), The Principle, Jossey-Bass, San Francisco, CA.

Geijsel, F.P., Sleegers, P.J.C., Stoel, R.D. and Krüger, M.L. (2009), "The effect of teacher psychological and school organizational and leadership factors on teachers' professional learning in Dutch schools", The Elementary School Journal, Vol. 109 No. 4, pp. 406427.

Hill, R. and Stewart, J. (2000), "Human resource development in small organizations", Journal of European Industrial Training, Vol. 24, pp. 105-117.

Hoekstra, A. (2007), Experienced teachers' informal learning in the workplace, Unpublished doctoral dissertation, IVLOS Institute of Education of Utrecht University, Utrecht.

House, J.S. (1981), Work stress and social support, Addison Wesley, Reading: MA.

Hox, J. (2002), Multilevel analysis: Techniques and applications, Erlbaum, London.

Karasek, R.A. (1979), “Job demands, job decision latitude, and mental strain: Implications for job redesign", Administrative Science Quarterly, Vol. 24 No. 2, pp. 285-308.

Kwakman, K. (2001), "Work stress and work-based learning in secondary education: Testing the Karasek model”, Human resource development international, Vol. 4 No. 4, pp. 487501.

Kwakman, K. (2003), "Factors affecting teachers' participation in professional learning activities", Teaching and teacher education, Vol. 19 No. 2, pp. 149-170.

Lee, I. (2008), “Understanding teachers' written feedback practices in Hong Kong secondary classrooms", Journal of Second Language Writing, Vol. 17, pp. 69-85.

Little, J.W. (1990), “The persistence of privacy: Autonomy and initiative in teachers' professional relations", Teachers College Record, Vol. 91 No. 4, pp. 509-536. 
Liu, D. and Fu, P.P. (2011), “Motivating proteges' personal learning in teams: a multilevel investigation of autonomy support and autonomy orientation", Journal of Applied Psychology, Vol. 96 No. 6, pp. 1195-1208.

Loewenthal, K.M. (2001), An introduction to psychological tests and scales, Psychology Press, Hove, UK.

Marsick, V.J. and Watkins, K.E. (2001), "Informal and incidental learning”, New Directions for Adult and Continuing Education, Vol. 89, pp. 25-34.

McGoldrick, J., Stewart, J. and Watson, S. (2002), Understanding Human Resource Development: A Research-based Approach, Routledge, London.

McGuire, D. and Cseh, M. (2006), “The development of the field of HRD: a Delphi study”, Journal of European Industrial Training, Vol. 30 No. 8, pp. 653-667.

Mikkelsen, A. and Grønhaug, K. (1999), "Measuring Organizational Learning Climate. A Cross-National Replication and Instrument Validation Study Among Public Sector Employees”, Review of public personnel Administration, Vol. 19 No. 31, pp. 31-44.

National Staff Development Council (2009), Professional learning in the learning profession: A status report on teacher development in the United States and Abroad, NSDC \& School Redesign Network, Stanford.

Nunnally, J.C. (1978), Psychometric Theory, McGraw-Hill, New York.

OECD (2009), Creating Effective Teaching and Learning Environments: First results from TALIS 2008, OECD, Paris.

OECD (2013), Fostering learning communities among teachers, OECD, Paris, Vol. 04, pp. $1-4$.

O’Leary, M.B., Mortensen, M. and Woolley, A.W. (2011), "Multiple team membership: a theoretical model of its effects on productivity and learning for individuals and teams", Academy of Management Review, Vol. 36 No. 3, pp. 461-478. 
Postholm, M.B. (2012), “Teachers' professional development: a theoretical review", Educational Research, Vol. 54 No. 4, pp. 405-429.

Retallick, J. (1999), “Teachers’ workplace learning: towards legitimation and accreditation”, Teachers and Teaching: theory and practice, Vol. 5 No. 1, pp. 33-50.

Rippon, J.H. (2005), "Re-defining careers in education”, Career Development International, Vol. 10 No. 4, pp. 275-292.

Runhaar, P. (2008), Promoting teachers' professional development, Unpublished doctoral dissertation, University of Twente, Twente.

Sahlstein, E. and Duck, S. (2001), "Interpersonal Relations: What we do with relationships", in Robinson, W.P. and Giles, H. (Eds), Handbook of language and social behavior, John Wiley, London, pp. 371-382.

Sheehan, K.B.E. (2001), "E-mail survey response rates: a review", Journal of Computer Mediated Communication, Vol. 6 No. 2, pp. 1-20.

Skule, S. (2004), "Learning conditions at work: a framework to understand and assess informal learning in the workplace", International journal of training and development, Vol. 8 No. 1, pp. 8-20.

Somekh, B. (Ed) (2005), "Learning for the Twenty-First Century: What Really Matters? [Special Issue]”, Education and Information Technologies, Vol. 10 No. 3.

Stok-Koch, L., Bolhuis, S. and Koopmans, R. (2007), "Indentifying factors that influence workplace learning in postgraduate medical education", Education for Health, Vol. 20 No. 1. pp. 1-9. Retrieved from http://www.educationforhealth.net/.

Stoll, L., Bolam, R, McMahon, A, Wallace, M. and Thomas, S. (2006), "Professional learning communities: A review of the literature", Journal of Educational Change, Vol. 7, pp. $221-258$. 
Tynjälä, P. (2008), "Perspectives into learning at the workplace", Educational Research Review, Vol. 3, pp. 130-154.

Van der Heijden, B.I.J.M. (1998), The measurement and development of occupational expertise throughout the career. A retrospective study among higher level Dutch professionals, Unpublished doctoral dissertation, University of Twente, Enschede, the Netherlands.

Van der Heijden, B.I.J.M. (2002), "Individual career initiatives and their influence upon professional expertise development throughout the career", International Journal of Training and Development, Vol. 6 No. 2, pp. 54-79.

Van der Heijden, B.I.J.M. (2003), “Organisational influences upon the development of occupational expertise throughout the career", International Journal of Training and Development, Vol. 7 No. 3, pp. 142-165.

Van der Heijden, B.I.J.M. and Bakker, A.B. (2011), "Toward a mediation model of employability enhancement: A study of employee-supervisor pairs in the building sector", The Career Development Quarterly, Vol. 59, pp. 232-248.

Van der Heijden, B.I.J.M., De Lange, A.H., Demerouti, E. and Van der Heijde, C.M. (2009), "Age effects on the employability-career success relationship", Journal of Vocational Behavior, Vol. 74 No. 2, pp. 156-164.

Van der Heijden, B.I.J.M., Gorgievski, M.J. and De Lange, A.H. (2015), "Learning at the workplace and sustainable employability: a multi-source model moderated by age", European Journal of Work and Organizational Psychology, (ahead-of-print), pp. 1-18. DOI: 10.1080/1359432X.2015.1007130

Van der Heijden, B.I.J.M., Scholarios, D., Bozionelos, N., Van der Heijde, C.M., Epitropaki, O. and the I. consortium (2005), Report on final results. Indic@tor Report: A cross- 
cultural study on the measurement and enhancement of employability in small and medium-sized ICT-companies, European Commission, Brussels, Belgium.

Van Ruysseveldt, J. and Van Dijke, M. (2011), "When are workload and workplace learning opportunities related in a curvilinear manner? The moderating role of autonomy", Journal of Vocational Behavior, Vol. 79 No. 2, pp. 470-483.

Van Veldhoven, M. and Meijman, T.F. (1994), Het meten van psychosociale arbeidsbelasting met een vragenlijst (VBBA) [The measurement of psychosocial work demands with a questionnaire (VBBA)], Dutch Institute of Working Conditions, Amsterdam.

Van Woerkom, M. (2003), Critical reflection at work. Bridging individual and organisational learning, Unpublished doctoral dissertation, University of Twente, Enschede, the Netherlands.

Van Woerkom, M., Nijhof, W.J. and Nieuwenhuis, L.F.M. (2002), "Critical reflective working behaviour: a survey research”, Journal of European Industrial Training, Vol. 26 No. 8, pp. 375-383.

Xanthopoulou, D., Bakker, A.B., Demerouti, E. and Schaufeli, W.B. (2007), "The role of personal resources in the job demands-resources model.", International Journal of Stress Management, Vol. 14 No. 2, pp. 121-141. 
Table 1. Sample Characteristics

\begin{tabular}{lcc}
\hline & Primary teachers & Secondary teachers \\
$n$ & 118 & 574 \\
\hline \multicolumn{1}{c}{$\%$} & $\%$ \\
\hline Mender & & \\
Women & 13.0 & 52.8 \\
Education & 87.0 & 47.2 \\
Low & & \\
Middle & .0 & 4.2 \\
Bachelor & 4.2 & .9 \\
Master & 90.7 & 73.2 \\
Age & 5.1 & 21.8 \\
$<21$ & & \\
$21-25$ & .8 & .2 \\
$26-30$ & 11.9 & 10.5 \\
$31-35$ & 9.3 & 9.2 \\
$36-40$ & 6.8 & 2.8 \\
$41-45$ & 16.1 & 7.7 \\
$46-50$ & 16.1 & 11.0 \\
$51-55$ & 16.9 & 13.2 \\
$56-60$ & 13.6 & 21.8 \\
$61-65$ & 5.9 & 18.1 \\
$>65$ & 2.5 & 5.6 \\
\hline
\end{tabular}


Table 2. Means, Standard Deviations, Reliability Coefficients (Cronbach's Alphas on the Diagonal), and Inter-Correlations between the Model Variables, $n=692$

\begin{tabular}{|c|c|c|c|c|c|c|c|c|c|c|c|c|c|c|c|c|c|c|c|c|c|c|c|c|}
\hline & $\mathrm{M}$ & SD & Range & 1. & 2. & 3. & 4. & 5. & 6. & 7. & 8. & 9. & 10. & 11. & 12. & 13. & 14. & 15. & 16. & 17. & 18. & 19. & 20. & 21. \\
\hline 1. primary/second. educ. & - & - & - & |- & & & & & & & & & & & & & & & & & & & & \\
\hline 2. gender & - & - & - & $.30 * *$ & - & & & & & & & & & & & & & & & & & & & \\
\hline 3. education & 3.11 & .58 & $1-4$ & $.08 *$ & .04 & - & & & & & & & & & & & & & & & & & & \\
\hline 4. age & 6.35 & 2.44 & $1-11$ & $.14 * *$ & $.25 * *$ & $.10^{*}$ & - & & & & & & & & & & & & & & & & & \\
\hline 5. learning climate & 2.03 & .51 & $1-4$ & $.25 * *$ & -.07 & $-.11^{* *}$ & $-.10^{* *}$ & .70 & & & & & & & & & & & & & & & & \\
\hline 6. team membership & 1.77 & .42 & $1-2$ & $.25 * *$ & $-.14^{* *}$ & -.04 & -.05 & .02 & - & & & & & & & & & & & & & & & \\
\hline 7. transformational leadership & 4.74 & 1.24 & $1-7$ & $.12^{* *}$ & $-.09 *$ & $-.09 *$ & $-.13^{* *}$ & $.51^{* *}$ & .03 & .95 & & & & & & & & & & & & & & \\
\hline 8. career possibilities offered & 3.17 & 1.47 & $1-7$ & .02 & .01 & $-.11^{* *}$ & $-.11^{* *}$ & $.40^{* *}$ & $-.09 *$ & $.42^{* *}$ & .90 & & & & & & & & & & & & & \\
\hline 9. social support supervisor & 3.52 & .98 & $1-6$ & .05 & $-.09 *$ & $-.13 * *$ & $-.21^{* *}$ & $.47 * *$ & .07 & $.72^{* *}$ & $.33 * *$ & .85 & & & & & & & & & & & & \\
\hline 10. social support colleagues & 3.76 & .83 & $1-6$ & .01 & $-.08 *$ & $-.15 * *$ & $-.19 * *$ & $.31^{* *}$ & -.02 & $.30^{* *}$ & $.23 * *$ & $.40^{* *}$ & .78 & & & & & & & & & & & \\
\hline 11. work pressure & 2.44 & .60 & $1-4$ & $.13^{* *}$ & -.06 & $.11^{* *}$ & .07 & $-.20^{* *}$ & .06 & $-.11^{* *}$ & $-.20^{* *}$ & $-.16^{* *}$ & $-.14^{* *}$ & .74 & & & & & & & & & & \\
\hline 12. emotional demands & 2.10 & .51 & $1-4$ & .07 & .03 & $.08 *$ & .06 & -.06 & -.02 & $-.13^{* *}$ & $-.09 *$ & $-.11^{* *}$ & -.07 & $.32^{* *}$ & .67 & & & & & & & & & \\
\hline 13. autonomy & 2.58 & .59 & $1-4$ & .04 & -.01 & -.07 & -.04 & $.22 * *$ & -.03 & $.15^{* *}$ & $.15 * *$ & $.19 * *$ & $.08 *$ & $-.35 * *$ & $-.12^{* *}$ & .82 & & & & & & & & \\
\hline 14. learning value function & 4.17 & .91 & $1-6$ & $.09 *$ & $-.09 *$ & $-.14^{* *}$ & $-.12^{* *}$ & $.36 * *$ & .06 & $.38^{* *}$ & $.23 * *$ & $.37 * *$ & $.25 * *$ & $-.10 *$ & -.01 & $.32^{* *}$ & .86 & & & & & & & \\
\hline 15. tasks apart from teaching & 1.64 & .48 & $1-2$ & $.28^{* *}$ & $.08 *$ & .07 & $.12^{* *}$ & -.07 & -.04 & -.04 & -.05 & .00 & -.06 & .02 & .05 & -.02 & .00 & - & & & & & & \\
\hline 16. reading & 2.72 & .70 & $1-4$ & .01 & -.00 & .02 & .03 & $.09 *$ & .02 & $.11^{* *}$ & $.09 *$ & $.11^{* *}$ & $.10^{*}$ & $.09 *$ & $.10^{* *}$ & .00 & $.18^{* *}$ & .01 & .73 & & & & & \\
\hline 17. work related training & 1.90 & .73 & $1-4$ & $.27 * *$ & $-.13^{* *}$ & -.04 & $-.12^{* *}$ & $.22 * *$ & .05 & $.15^{* *}$ & $.12^{* *}$ & $.14^{* *}$ & $.10^{*}$ & .03 & .02 & $.08 *$ & $.17^{* *}$ & -.06 & $.31^{* *}$ & .72 & & & & \\
\hline 18. experimenting & 2.32 & .63 & $1-4$ & .01 & -.03 & .05 & -.05 & $.08^{*}$ & .04 & $.12^{* *}$ & $.10^{* *}$ & $.12^{* *}$ & $.13 * *$ & .04 & .05 & .07 & $.13^{* *}$ & -.02 & $.40^{* *}$ & $.19 * *$ & .80 & & & \\
\hline 19. reflecting \& ask. feedback & 2.37 & .57 & $1-4$ & .05 & -.06 & .01 & -.07 & $.11^{* *}$ & .04 & $.14^{* *}$ & $.10^{*}$ & $.21^{* *}$ & $.22^{* *}$ & $.08 *$ & $.12^{* *}$ & .07 & $.24^{* *}$ & -.03 & $.35 * *$ & $.25 * *$ & $.48^{* *}$ & .67 & & \\
\hline 20. collaborating lessons & 2.42 & .65 & $1-4$ & $.23 * *$ & $-.20^{* *}$ & -.03 & -.07 & $.22 * *$ & $.09 *$ & $.21^{* *}$ & $.10 *$ & $.24 * *$ & $.36 * *$ & .06 & .01 & $.08 *$ & $.21 * *$ & $-.13^{* *}$ & $.26 * *$ & $.20 * *$ & $.40^{* *}$ & $.41^{* *}$ & .67 & \\
\hline 21. collaborating school devel. & 2.50 & .67 & $1-4$ & $.27 * *$ & $-.10^{* *}$ & .01 & -.01 & $.24 * *$ & $.11 * *$ & $.20 * *$ & .05 & $.24^{* *}$ & $.22^{* *}$ & $.13^{* *}$ & .06 & $.08^{*}$ & $.19^{* *}$ & $.10^{* *}$ & $.23^{* *}$ & $.29 * *$ & $.27 * *$ & $.28 * *$ & $.46^{* *}$ & .73 \\
\hline
\end{tabular}

Note. ${ }^{*}$ Correlation was significant at the .05 level (two-tailed)

** Correlation was significant at the .01 level (two-tailed) 
Table 3. Hierarchical Regression Analyses with Demographic Characteristics, Organisational and Task Factors as Predictors, and Participation in TPD at Work Activities as Dependents, $n=692$

\begin{tabular}{|c|c|c|c|c|c|c|}
\hline \multirow[t]{2}{*}{ Predictors } & \multicolumn{6}{|c|}{ Dependent variables } \\
\hline & $\begin{array}{l}\text { Keeping up- } \\
\text { to-date: } \\
\text { reading }\end{array}$ & $\begin{array}{l}\text { Keeping up-to- } \\
\text { date: work- } \\
\text { related training }\end{array}$ & $\begin{array}{l}\text { Experime } \\
\text { nting }\end{array}$ & $\begin{array}{l}\text { Reflecting } \\
\text { and asking } \\
\text { feedback }\end{array}$ & $\begin{array}{l}\text { Collaborating } \\
\text { lesson }\end{array}$ & $\begin{array}{l}\text { Collaborating } \\
\text { school }\end{array}$ \\
\hline \multicolumn{7}{|l|}{ Step 1} \\
\hline Primary/second. educ. & .00 & $-.22 * *$ & .04 & $.11^{* *}$ & $-.14 * *$ & $-.27 * *$ \\
\hline Gender & .01 & -.04 & -.01 & -.04 & -.12 & .00 \\
\hline Educational qualification & .04 & .01 & $.08^{*}$ & .06 & .04 & .06 \\
\hline Age & .07 & -.05 & -.02 & -.01 & .07 & .06 \\
\hline \multicolumn{7}{|l|}{ Step 2} \\
\hline Learning climate & .00 & $.10^{*}$ & -.02 & .00 & .03 & $.09 *$ \\
\hline Team membership & .02 & -.02 & .05 & .04 & .03 & .04 \\
\hline \multicolumn{7}{|l|}{ Step 3} \\
\hline Transformational leadership & .01 & -.01 & .03 & -.06 & .01 & -.02 \\
\hline $\begin{array}{l}\text { Career possibilities offered by the } \\
\text { supervisor }\end{array}$ & .06 & .06 & .07 & .04 & -.01 & -.04 \\
\hline Social support immediate supervisor & r .05 & .03 & .03 & $.15^{* *}$ & .08 & $.16^{* *}$ \\
\hline Social support close colleagues & .06 & .02 & $.10^{*}$ & $.15^{* *}$ & $.32 * *$ & $.18^{* *}$ \\
\hline \multicolumn{7}{|l|}{ Step 4} \\
\hline Work pressure & .08 & .04 & .08 & $.13^{* *}$ & $.11^{* *}$ & $.15^{* *}$ \\
\hline Emotional demands & $.09 *$ & .04 & .05 & $.10^{* *}$ & .03 & .06 \\
\hline Autonomy & -.04 & .03 & .06 & .05 & .05 & .07 \\
\hline Learning value of function & $.16^{* *}$ & .08 & .07 & $.17^{* *}$ & .07 & .05 \\
\hline Tasks apart from teaching & .00 & .02 & -.03 & -.06 & -.07 & $.18^{* *}$ \\
\hline \multicolumn{7}{|l|}{ Model summary } \\
\hline Step $1 \Delta \mathrm{R}$ square & .00 & .08 & .01 & .01 & .07 & .08 \\
\hline Step $2 \Delta \mathrm{R}$ square & .01 & .02 & .01 & .02 & .03 & .04 \\
\hline Step $3 \Delta \mathrm{R}$ square & .02 & .01 & .02 & .05 & .11 & .05 \\
\hline Step $4 \Delta \mathrm{R}$ square & .04 & .01 & .02 & .06 & .02 & .06 \\
\hline Full model R square & .07 & .12 & .06 & .14 & .23 & .23 \\
\hline Overall F & $3.12^{* *}$ & $6.09 * *$ & $2.53^{* *}$ & $7.12^{* *}$ & $13.37 * *$ & $13.28 * *$ \\
\hline
\end{tabular}

Note. Standardised regression coefficients (Beta) shown for the last step in the regression.

$* p<.05 * * p<0.01$. 


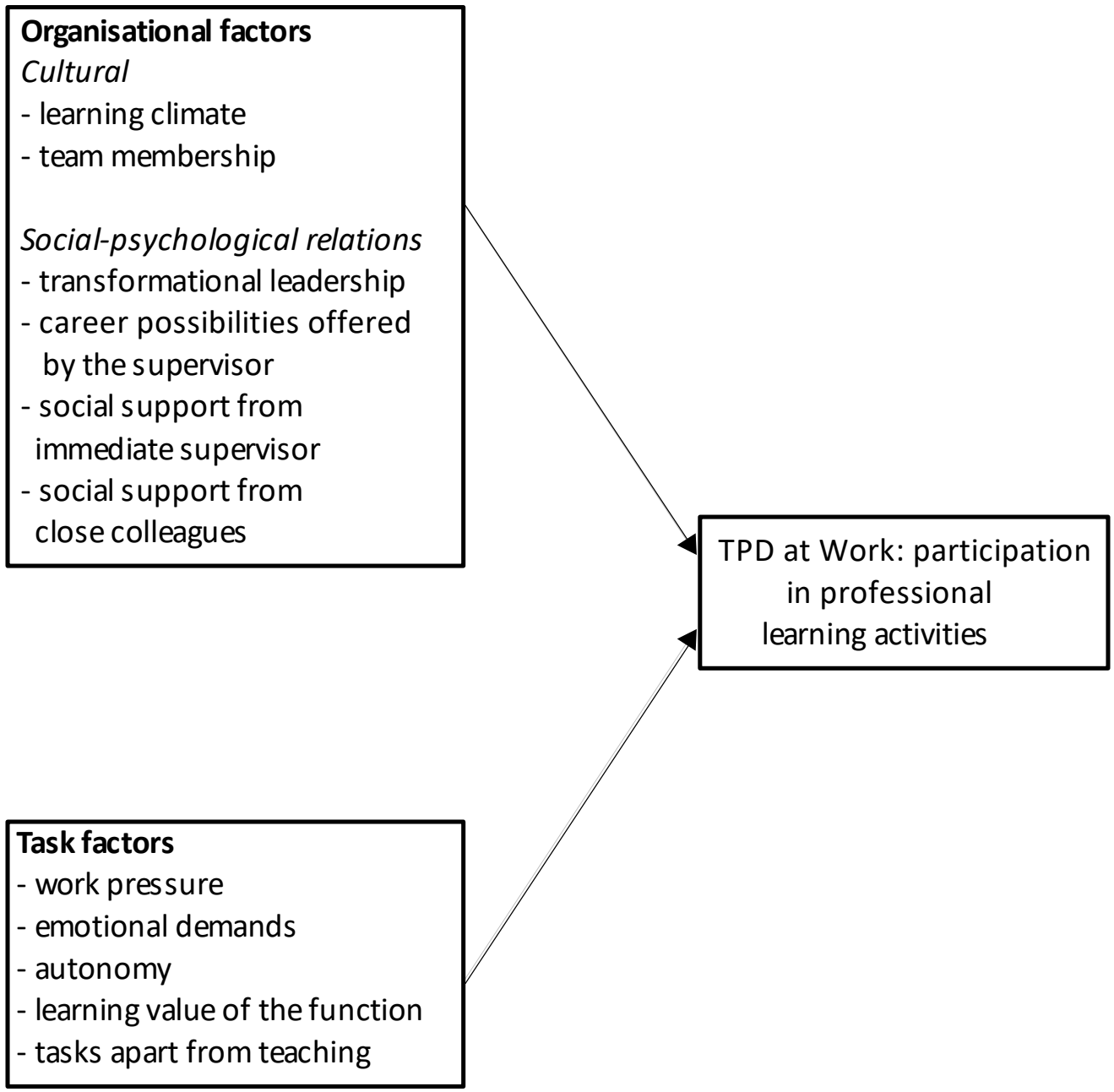

Figure 1. The TPD at Work Model 